Review article

\title{
Analysis of the Transdanubian region of Hungary according to plant species diversity and floristic geoelement categories
}

\author{
Dénes Bartha $^{1^{* \dagger}}$, Viktor Tiborcz ${ }^{1^{*}}$ \\ *Authors with equal contribution \\ ${ }^{1}$ Department of Botany and Nature Conservation, Faculty of Forestry, University of West Hungary, H-9400 \\ Sopron, Bajcsy-Zsilinszky 4, Hungary
}

\begin{abstract}
Bartha, D., Tiborcz, V., 2017. Analysis of the Transdanubian region of Hungary according to plant species diversity and floristic geoelement categories. Folia Oecologica, 44: 1-10.

The aim of this study was to describe the proportion of floristic geoelements and plant biodiversity in the macroregions of Transdanubia. The core data source used for the analysis was the database of the Hungarian Flora Mapping Programme. The analysed data were summarized in tables and distribution maps. The percentage of continental elements was higher in dry areas, whereas the proportion of circumboreal elements was higher in humid and rainy parts of Transdanubia. According to the climatic zones, the highest value of continental geoelement group occurred in the forest-steppe zone. The plant species diversity and geoelements were analysed also on a lower scale, with Transdanubia specified into five macroregions. The highest diversity values were found in the Transdanubian Mountain and West-Transdanubian regions because of the climatic, topographic, and habitat diversity.
\end{abstract}

\section{Keywords}

Borhidi's climatic zones, climatic variables, floristic geoelement categories, macroregion, species diversity, Transdanubia

\section{Introduction}

Hungary is influenced by many different environmental conditions which are also reflected in the floristic diversity. The Hungarian territory is a meeting point of floristic and biogeographical regions; therefore many differences are present in the distribution pattern of floristic elements. The floristic geoelements can reflect the relation between historical and recent data of flora, and this can also refer to the flora origin. Some of these elements have connection with climatic differences and changes; the distribution area of plants will likely change along with the climate, which will influence the proportion of floristic elements.
In some European countries, floristic assessments have already been made based on published flora atlases. In Switzerland the proportion of Atlantic floristic elements was compared with the proportion of Atlantic elements in Europe (KozlowsKi et al., 2009). The Polish flora atlas was published (ZAJAC and ZAJAC, 2001a, $2001 \mathrm{~b}$ ) and on the basis of this work eastern and southeastern distribution limits for 2,300 plant species were analysed, along with the proportion of floristic elements (ZAJAC and ZAJAC, 2006). The biogeographical relations of Middle-Vistula were analysed according to the data of the Polish flora atlas (KUCHARCZYK, 2003). Researchers

$\dagger$ Corresponding author:

e-mail: bartha.denes@emk.nyme.hu

(C) 2017 Authors. This is an open access article under the CC BY-NC-ND license (http://creativecommons.org/licenses/by-nc-nd/3.0/) 
made conclusions about the connection between the climate change, plant diversity, and plant distribution patterns in Netherland (WIL et al., 2005; WITTE and VAN DER MEIJDEN, 1995). Flora atlas of Switzerland was also published by WeLten and SutTER (1982).

The flora atlas of Germany also sets out information about the quadrate's plant diversity (HAUPLER and SCHONFELDER, 1988; BETTINGER et al., 2014). The flora atlas of the Czech Republic containing distribution maps for all taxa has not been published yet, but some of the maps appeared in publications (SLAvík, 1986, 1990, 1998; ŠTĚPÁNKová, 2012). A proposal was made about the classification of Czech taxa into floristic categories (KAPLAN, 2012). The Slovenian flora atlas (JoGAN et al., 2001) can serve as basis for further phytogeographical analysis. The Dacian migroelement was analysed and evaluated in the area of Slovakia by HENDRYCH and HeNDrychova (1979). This study also highlighted to the migration way of this elements. The distribution of arctic-alpine elements in the Western Carpathians in relation to the environmental factors was evaluated by Slovak researchers (ŠiBíkoví et al., 2010).

Atlas Flora Danica was published at the end of 2015 (Hartvig, 2015). It contains 2,125 distribution maps and also information about the species and subspecies such as origin, habitat preference of the different taxa.

The first Hungarian work about the distribution of tree and shrub species in the Carpathian basin was published in 1913 (FeKete and Blattny, 1913): This study examined the horizontal and vertical distribution limits of the species relevant. The distribution maps of tree and shrub species were renewed by BARTHA and MÁTYÁs, (1995). In the recent years the Distribution atlas of rare tree and shrub species (BARTHA, 2012), and the Distribution atlas of orchids (MoLNÁR, 2011) were also published. With the completion of Hungarian Flora Mapping Programme, Distribution atlas of vascular plants of Hungary was published (BARTHA et al., 2015), with 2,231 distribution maps of Hungarian taxa. In this study we highlighted the floristic geoelements distribution in Transdanubian region of Hungary.

There are only a few published studies about the analysis of floristic geoelements distribution in Hungary. The composition and percentage of floristic elements of the Hungarian flora are known from earlier publications (Soó and MáTHÉ, 1938; Soó, 1939; Pócs, 2000), but the distributions in particular macroregions have not been recognised yet. The purpose of this study is to fill this gap for the Transdanubian region of Hungary.

\section{Materials and methods}

\section{Examination methods}

The proportions of floristic geoelements in quadrates were calculated based on the absence and presence data from the Hungarian Flora Mapping database (Database of Hungarian Flora Mapping Programme). We also compared the average and deviation of floristic geoelements according to Borhidi's climatic regions. The vertical and horizontal patterns of floristic elements were examined. The Central European Grid Map System (EHRENDORFER and Haman, 1965; NiKLFELD, 1971), dividing the area of Hungary into quadrates according to the geographical coordinate system (KIRÁLY, 2003), was used as a basic research unit. We focused on the Transdanubian region of Hungary because the Central European flora list (EHRENDORFER, 1973) separates it from the other parts of Hungary which are considered belonging to south-eastern Europe. This study analyses percentage of floristic elements and plant biodiversity.

Until now some studies were published about the classification of European taxa into floristic geoelements. The attempts to determine floristic element categories (FINNIE et al., 2007) were based on the distribution maps of Atlas florae Europaeae (JALAS and SuOMINEN, 1972-1994; JALAS et al., 1996, 1999). This Atlas only covers $20 \%$ of European flora; therefore, we could not use it for the Hungarian taxa. There were early publications about the geoelements of Hungarian flora (MáTHÉ, 1940, 1942), but our study works with a synthesis published later in Hungarian literature (RÉDEI and HoRvát, 1995; SimON, 1992). In this study 2,459 taxa of Hungary were classified into geoelement categories. We need to mention that only taxa native to Hungary were used in this analysis. To ensure better evaluation, some categories were necessary to combine. The following floristic geoelement categories were used: cosmopolitan, circumboreal, eurasian, european, central-european, continental group (continental-, pontic-, pontic-submediterranean, pontic-pannonian, turanian-geoelements), submediterranean group (mediterranean-, submediterranean-, east-submediterranean, pannon-balkanian, balkanian, illyric geoelements), sub-atlantic group, (alpine-, central-european-alpine, alpine-balkanian, dacian-geoelements), boreal.

The proportion of floristic geoelements was calculated in each quadrate. We used Borhidi's climatic zones (BoRHIDI, 1961) for analysing the connections between floristic geoelements. The climatic zone classification is based on the evaluation of climatic factors, thus it helped us to evaluate distribution patterns related to complex climate.

To evaluate climatic conditions the following parameters were chosen: average precipitation ( $\mathrm{P} \_$year), vegetation period average precipitation ( $\mathrm{P}_{-}$veg), mean temperature ( $\mathrm{T}$ year), vegetation period mean temperature (T_veg). From these parameters were derived the following indexes: forest aridity index (FAI) (FÜHRER et al., 2011), modified Ellenberg index (ELLENBERG, 1988), winter cold stress (WCS), summer drought stress (SDS) (MitraKos, 1980). The climatic parameters originate from CARPATCLIM project (LAKATOs et al., 2013), moreover interpolation to the quadrate scale was carried out on climatic data. 
R 2.15 statistical programme was used for multivariate statistical analysis (R DEVELOPMENT CORE TEAM, 2008). The connection between climatic variables and floristic geoelements was evaluated through correlation matrix. Pearson's correlation and t-test were used at 95\% confidence interval.

\section{Study area}

The area of Transdanubia is about 28 thousand $\mathrm{km}^{2}$, consisting of diverse topography including plains, hilly areas and mountains. There are 2,834 quadrates in the area of Hungary, with 1,220 quadrates situated in Transdanubia. This accounts for $43 \%$ of all quadrates in Hungary. Most (349) of the quadrates are located in the South-Transdanubian region, 252 quadrates are in the Great Hungarian Plain region, 245 quadrates are in the West-Transdanubian region, 207 quadrates are in Transdanubian Mountain and the smallest region is the Little Hungarian Plain with 165 quadrates.

The climate of Transdanubia is in the subcategory of continental wet climate zone according to Trewarthasystem (Trewartha and Horn, 1980), where the basin effect is strong. There are many climatic effects in Hungary such as rainy oceanic, hot and dry continental, and the Mediterranean climate with dry summer and wet winter. In the South-Transdanubian (Dél-Dunántúl) region the submediterranean climate is most characteristic; in the West-Transdanubian (Nyugat-Dunántúl) region the wet subatlantic climate is characteristic, while in the Little Hungarian Plain (Kisalföld) and Great Hungarian Plain (Nagyalföld) the drier sub-continental climate is typical. In the area of Transdanubian Mountains (Dunántúli-középhegység), the subcontinental, submediterranean and subatlantic climates equally have impact resulting in part from topological diversity (PÉCZELY, 1981).

The annual mean temperature in flatland areas is between $10-11^{\circ} \mathrm{C}$, in hilly lands of West-Transdanubia, South-Transdanubia and Transdanubian Mountain it is between $9-10{ }^{\circ} \mathrm{C}$, in the mountainous areas it is under 9 ${ }^{\circ} \mathrm{C}$. The south-western part of Transdanubia is the most humid area because of the oceanic effect from the west and Mediterranean effect from the south. The annual average precipitation is decreasing from south-west to north-east. The highest precipitation is in the southwestern part of Transdanubia, whereas in higher regions of mountains the annual precipitation can be above 800 $\mathrm{mm}$. From west to east the precipitation is continuously decreasing (CsAPó et al., 2012).

\section{Results}

The distribution of species diversity per quadrate by region is shown in Table 1. In the area of Transdanubian
Mountain, there are 19 quadrates in which the number of species is higher than 600 (Vértes, Bakony). In the WestTransdanubian region, the species richness is also high, with 45 quadrates containing more than 500 species, for example in Sopron-hill and Köszeg-mountain. The species diversity is varying in the South Transdanubian region where the species number exceeds 600 only in 4 quadrates (Mecsek-hill), while in most of the quadrates is this number less than 400. In the region of Little Hungarian Plain, the species number is higher than 300 in 125 quadrates (Szigetköz, Győr) and only 40 quadrates contain less than 300 species. There are 254 quadrates in the area of Great Hungarian Plain, and 187 of them contain less than 300 species. This region's species richness is the lowest, while the highest species diversity occurs in the Transdanubian Mountain region and in WestTransdanubia (Table 1). The highest species number is registered in a West-Transdanubian quadrate in the area of Sopron-hill with 896 plant species altogether.

The highest proportion is shown by the Eurasian floristic geoelements $(33.92 \%)$, followed by the group of cosmopolitan elements (14.09\%), and European elements $13.83 \%$, circumboreal elements were represented by $8.98 \%$. The remaining regions include submediterranean elements with $7.54 \%$, continental elements with $6.62 \%$, central-European elements with $5.13 \%$, subatlantic elements with $1.99 \%$, and the subboreal elements have the lowest proportion representing $0.38 \%$ (Table 2 ).

The differences in proportion amongst the cosmopolitan floristic elements are significant, with the highest value in a quadrate located in the area of Budapest [8580.2], while this floristic element is lacking in five quadrates, for example [9073.4; 9180.2], the first one is located in Lake Balaton, the second is situated in a quadrate where only arable fields are present without any settlements. Example species of this floristic geoelement are Arabidopsis thaliana, Malva sylvestris. The average value in the area of Transdanubia is $14.09 \%$.

The value of circumboreal floristic elements is the highest $17.73 \%$ [8964.4] in the western part of the Transdanubia, while the lowest value is $2.00 \%$ in a transition quadrate between the South-Transdanubian and Great Hungarian Plain regions. The average value of circumboreal floristic element is $8.98 \%$ in the area of Transdanubia. Distribution of Vaccinium vitis-idaea is an example for this geoelement pattern.

The proportion of Eurasian floristic elements is the highest in Transdanubia, the average value is $33.92 \%$, in most of the quadrates it varies between $20 \%$ and $40 \%$. The highest value is $55.73 \%$ in a quadrate [9775.3] located in the area of Mecsek-hill. Scrophularia nodosa, Gypsophila muralis, Lepidium perfoliatum can be mentioned as example species. According to different climatic zones, the highest value $(34.90 \%)$ is identified in montane zone, whereas the smallest proportion appear in forest steppe zone (31.17\%). 


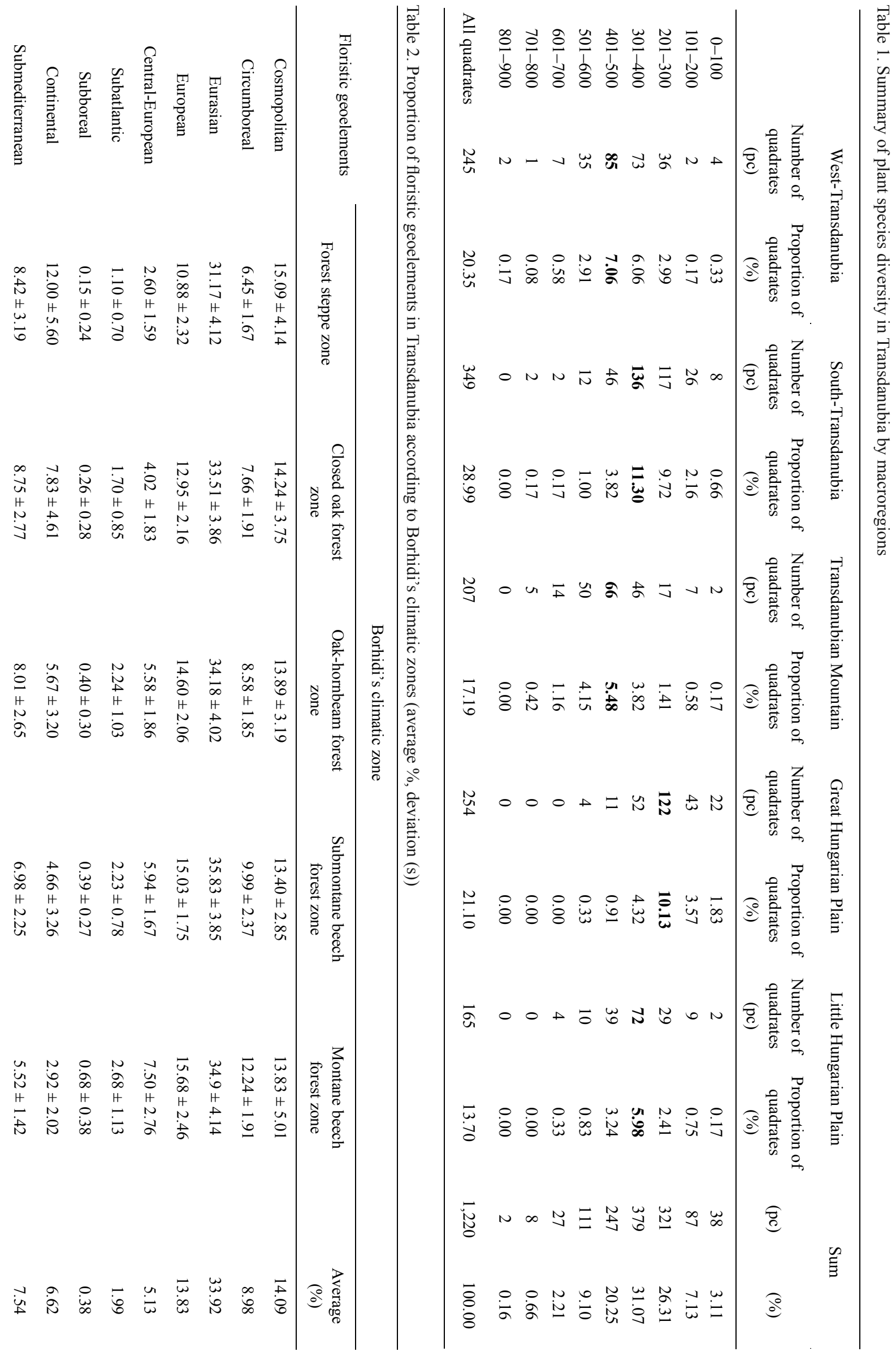


The proportion of European floristic elements is diverse in Transdanubia. The highest value is in the South Transdanubian region with quadrate value of $26.37 \%$ [9775.3]. In the area of the Great and Little Hungarian Plains this percentage is lower than in the area of Transdanubian Mountain and West-Transdanubian regions. Campanula patula and Mycelis muralis distribution are presenting this geoelement. From the viewpoint of different climate zones, the proportion of these species are the highest in the montane zone $(15.68 \%)$, while in forest steppe zone it is only $10.88 \%$. The average value of European elements is $13.83 \%$.

Species belonging to the central-European floristic category occur in $92 \%$ of the quadrates. The distribution fluctuated considerably, with the highest value of $12.50 \%$ in a quadrate [9068.2] situated close to the western part of Transdanubian mountain and the lowest $0.29 \%$ in a quadrate [8875.1] near to the eastern part of Balaton. Its average proportion is $5.13 \%$ in Transdanubia. Example species are Trifolium alpestre and Lembotropis nigricans. In montane climate zone the proportion is $7.50 \%$, while in forest steppe zone it is $2.60 \%$.

The subatlantic floristic geoelement pattern is similar to the circumboreal one. The highest value is shown in a West-Transdanubian quadrate (Zselic) [9772.1] with a proportion of 5.05\%. Mostly in the area of Transdanubia the value of this geoelement is low. Distribution pattern of Calluna vulgaris and Doronicum austriacum represents the area of the highest value of this geoelement. According to the climatic zones, the subatlantic element value is the highest in montane zone $(2.68 \%)$, whereas in forest steppe it is the lowest $(1.10 \%)$.

The subboreal floristic element group value is in accordance with the altitude. Distribution of Ribes alpinum is an example of subboreal element group. The highest value $(1.75 \%)$ is detected in a quadrate of Transdanubian Mountain (Bakony) [8672.2], whereas in the Great and Little Hungarian Plains it is mostly $0.00 \%$. According to climatic zones the highest value is $0.68 \%$ in montane zone.

The highest value of continental floristic geoelement group is $29.8 \%$ [8878.4], this quadrate is located in the Great Hungarian Plain (Mezöföld), where occur dry grassland habitats with typical continental taxa such as Achillea pannonica, while in the western part of Transdanubia, close to the country border, the proportion of this element is less than $2 \%$. The examination of climatic zones resulted the highest proportion in forest steppe zone with $12.00 \%$. The average value is $6.62 \%$ in Transdanubia.

For the submediterranean floristic geoelement group, the highest value $(19.46 \%)$ is presented in the Transdanubian Mountain region [8576.4] (Vértes). Similar proportion $(16.86 \%)$ is in the quadrates of South Transdanubian region [0175.2] Villány-hill, with a number of submediterranean taxa such as Trinia glauca, Ruscus hypoglossum. The average proportion is $7.54 \%$ in Transdanubia.

Continental element had positive relation with forest aridity index (FAI), modified Ellenberg index and summer drought stress (SDS). Positive relation showed between precipitation, subatlantic and circumpolar element proportion. In the west part of Transdanubia the precipitation and proportion of these elements were higher. Temperature parameters, forest aridity index and modified Ellenberg index manifested negative correlation with subatlantic floristic geoelements (Table 3), low negative correlations were detected between FAI, Ellenberg, SDS and circumpolar, Eurasian, boreal and central-European floristic geoelements. Correlation was little between climatic variables and submediterranean, Eurasian, boreal elements.

\section{Discussion}

The plant species diversity of Transdanubia is evaluated according to the geographic macroregions (Table 1).

The number of species is high in many quadrates of the Transdanubian Mountains which can be explained by the altitude, geological conditions and habitat diversity. The quadrates with the highest species numbers are situated in the north-eastern part of the mountains. The species diversity was backed-up by the relief and diversity of bedrock; this area was mostly situated on limestone, dolomite, and locally occurring andesitic bedrock. The Transdanubian Mountain's species diversity was high compared to the other macroregions.

In the area of West-Transdanubia, the species diversity is also high in many quadrates. According to Borhidi's climate categories montane-, submontane beech, oak-hornbeam and oak forest zones were also presented in this region, which demonstrates the climatic diversity of the area. Topographical features and geological properties were also varying; hills such as Sopron-hill and mountains (Köszeg-mountain) were presented in the region with different kinds of habitats which resulted in the higher plant species diversity. The annual precipitation was high in the western part of this region, which can cause the occurrence of wetland habitats and also influence the distribution of taxa with humid preferences.

The plant species diversity is varying on a large scale in the South-Transdanubian region. Quadrates with high species numbers are situated in Mecsek-hill [9874.4; 9974.2; 9975.1], owing to the diversity of topographical features. The highest parts are situated in Mecsek and Villány-hill, contrarily, this region only contains lower regions for the most part. Taking into consideration the climatic regions, the bigger part of the area is covered by oak forest zone and the rest is situated in oak-hornbeam (79 quadrates) and submontane beech zone (6 quadrates). 


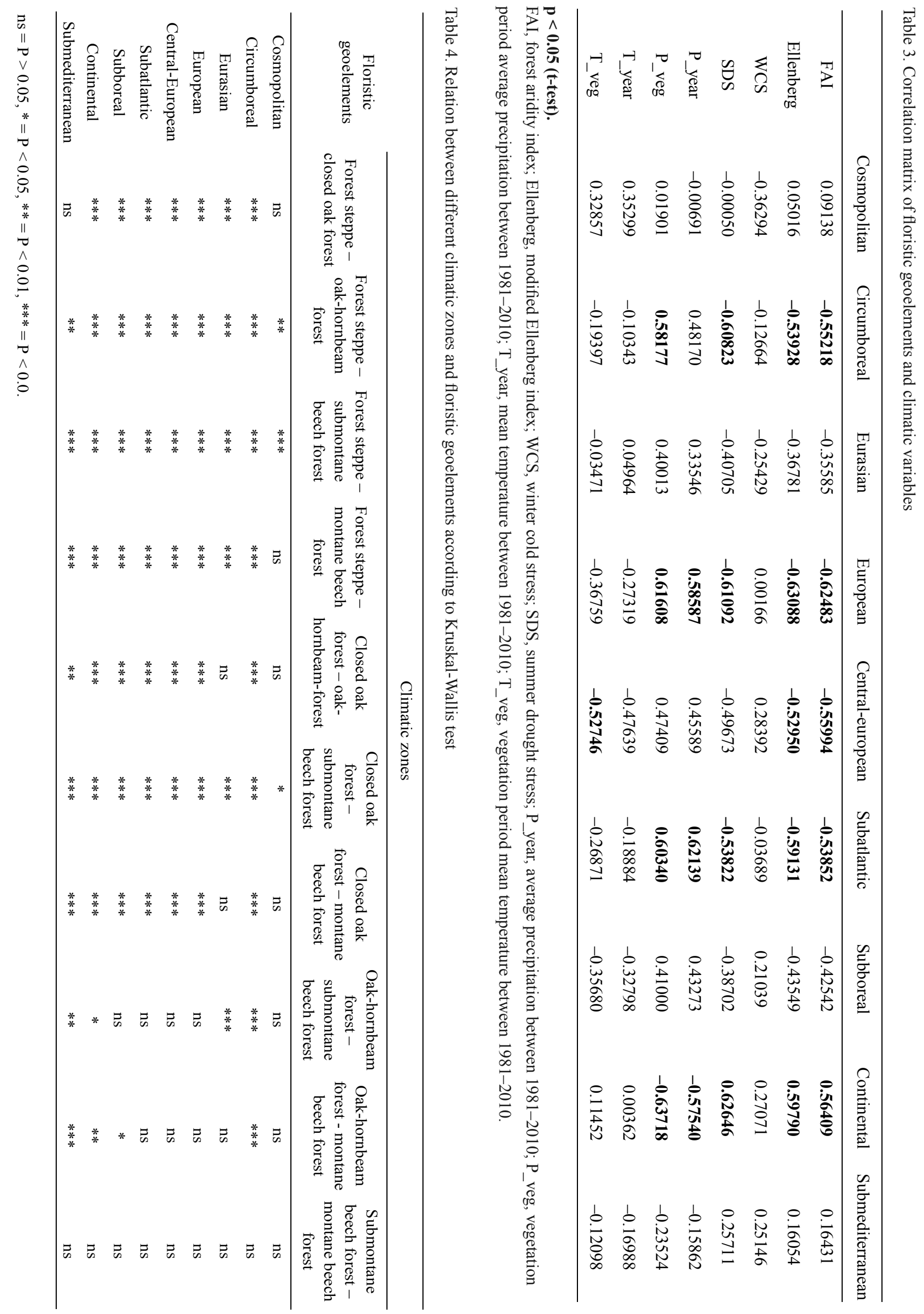


Compared with other macroregions, we conclude that plant species diversity is higher than in the lowland regions. On the other hand in West-Transdanubian and Transdanubian Mountain regions it exceeded the data of this region.

The plant diversity is low in most of the quadrates of the Great Hungarian Plain. The reason was the monotony of topographical features, where the altitude only varies between 75-200 meters. From geological point of view soils consist of mostly floodplain sand, loess and loessic deposits, thus there were not many habitat types in this region. All of the area was situated in the forest steppe climatic zone. Additionally the human impact demonstrated by a high proportion of arable fields also decreased the plant diversity.

We may postulate that the higher plant species diversity was due to climatic circumstances, habitat diversity and topographical features.

The proportions of some floristic geoelements are different from Borhidi's climatic zones. In the following section we examine this issue.

We could not detect significant differences in east-west and north-south directions in the proportion of cosmopolitan floristic geoelements. The connection between different climatic regions was low, as it was expected. In the area of hills and mountains the proportion was lower, likely due to the lower level of human impact. Contrarily, in lowlands, where agricultural production and inhabited areas dominated, the value was higher. Cosmopolitan floristic elements have a large distribution area, their proportion is high throughout the study area, therefore the climatic conditions did not influence the distribution (Table 3).

There were no significant differences between submontane- and montane beech zone in none of floristic geoelements; however, the proportion of circumboreal elements was significant in these zones. The value of these elements decreased from west to east corresponding to the decreasing precipitation. Climate was colder in West-Transdanubia, and this value was decreasing in eastward direction as well. Boreal element was concentrated in northern Europe but extended into the temperate zone of Europe (FINNIE et al., 2007). In montane and submontane beech zones this element reached its highest value, but in forest steppe zone it was only represented with few percent. This result also supported our conclusion that there was a close relationship between humidity, cold climate and subboreal floristic elements.

The highest proportion in Transdanubia is shown by the Eurasian floristic elements. There were no significant differences between the proportions experienced in each region, but we could recognize a small increasing tendency from east to west (forest steppe zone to submontane beech zone as well) which was caused by the humid character of the West-Transdanubian region (Table 2). There was no close relation between relief, climatic zones and proportion of Eurasian elements, therefore we could not recognize separated patches in the distribution pattern.

There was an increasing tendency from forest steppe zone to montane beech zone in the proportion of European floristic elements, but without significant differences (Table 2). According to the distribution pattern we concluded that in case of hilly and mountainous areas the proportion of European elements was higher than in case of lowlands, with altitude being the determining factor. Analysing the distribution map we could not recognize significant differences in east-west and north-south direction.

According to our results, Central-European floristic elements distribution pattern is similar to that of European elements. According to literature Central-European element in part is similar to Ranunculus bulbosus element which is also presented increasing value with higher altitude (FINNIE et al., 2007). The value increased from forest steppe zone to montane beech zone (Table 2). According to the map we could see that relationship was associated with relief and altitude, namely it was higher in mountainous regions and West-Transdanubia.

The proportion of subatlantic elements was significant in the western part of Transdanubia, which can be explained with climatic features; with the value decreasing from west to east. Subatlantic species descend from Alpine mountains to the area of Hungary, and humid, cold climate facilitates their spreading; which explains why their proportion was higher in the West-Transdanubian region (Table 2). In Poland subatlantic species has their eastern distribution limit, which means proportion decreasing from east to west (ZAJAC and ZAJAC, 2006). Our results suggested the same tendency in Transdanubia. Related to the climatic zones, the value grew from forest steppe zone to montane beech zone.

The proportion of subboreal floristic elements was consistent in relation to altitude. The highest value was obtained for the montane climatic zone. In submontane, oak-hornbeam and oak forest zones it was lower, and it is almost absent in the forest steppe zone on the lowlands (Table 4). As this element was rather dependent on the altitude in the studied area, there was no difference in the proportion in east-west and north-south direction.

In terms of continental floristic elements proportion we saw that the value is increasing from west to east, from montane beech forest zone to forest steppe zone (Table 2). In the eastern part of Transdanubia values were higher because of the lowland landscape, and the semi-arid, drier character of the climate; mostly the typical continental taxa occured in these areas. Continental floristic elements include pontic-pannonian elements which proportion is higher in arid lowland regions.

Proportion of submediterranean floristic elements is the most significant in the area of Transdanubian Mountain and the South-Transdanubian region. This result also highlighted that the submediterranean climate 
effect was the strongest in this part of Transdanubia. Submediterranean plants originate from the Southern European region, and their proportion was notably decreasing northwards beyond the Transdanubian Mountain. Submediterranean element includes Illyrian and Balkan elements, too. In Europe, the proportion of these elements is high in the south-eastern part of Europe and in south-Europe (FINNIE et al., 2007). The average value of the quadrates is the highest in the forest steppe and oak forest climate zones; whereas the lowest value occur in submontane and montane beech forest zones (Table 2).

\section{Conclusions}

We conclude that floristic elements can be categorised according to the vertical and horizontal changes in their proportion value (Table 2 ). Considering floristic elements, there were no significant differences in either horizontal or vertical direction in proportion of cosmopolitan and Eurasian floristic elements. The relation between different climatic zones and variables was weak for these two elements (Table 3). Vertical variability was observed in the proportion of subboreal, European and central European floristic elements. This conclusion highlighted the relation of these elements to the altitude. We had not found horizontal relationships in the proportions of these floristic elements. European element manifested relations with precipitation variables. Contrarily, there was detected horizontal relationship for circumboreal and subatlantic elements proportions, with their values increasing from east to west. In the western part of Transdanubia there were the highest proportions of these elements, whereas in the eastern part their proportions were lower. Subatlantic element was correlated with precipitation values. The pattern of continental floristic element proportion was the opposite, showing that the highest value was represented in the eastern part of Transdanubia because of dry climatic conditions of this area. Continental element was in correlation with forest aridity, modified Ellenberg index, and summer drought stress (Table 3). Drier condition predicted in future can promote the spreading of continental species. Horizontal changes were observed in the proportion of submediterranean floristic elements as well; however, it increased from north to south, and this represented the stronger submediterranean climatic effect present in South-Transdanubia. This element displayed a slight relation to climatic variables.

\section{References}

BARTHA, D., Mátyás, CS. (eds), 1995. Erdei fa- és cserjefajok előfordulása Magyarországon [Distribution of forest trees and shrubs in Hungary]. Sopron: Own Edition. 221 p.
BARTHA, D. (eds), 2012. Magyarország ritka fa- és cserjefajainak atlasza [Atlas of rare Hungarian tree- and shrub species]. Budapest: Kossuth Kiadó. 351 p.

Bartha, D., Király, G., Schmidt, D., Tiborcz, V., BARINZA, Z., CSIKY, J., JAKAB, G., LeskU, B., Schmotzer, A., Vidéki, R., VojtKó, A., Zólyomi, Sz. (eds), 2015. Magyarország edényes növényfajainak elterjedési atlasza [Distribution atlas of vascular plants of Hungary]. Sopron: Nyugat-magyarországi Egyetem Kiadó/University of West Hungary Press. 329 p.

Bettinger, A., Buttler, K.P., Caspari, S., Klotz, J., MaY, R., Metzing, D. (eds), 2014. Verbreitungsatlas der Farn- und Blütenpflanzen Deutschlands [Distribution atlas of fern and flowering plants of Germany]. Bonn: Netzwerk Phytodiversität Deutschlands e. V. und der Bundesamt für Naturschutz. 912 p.

BorhIDI, A., 1961. Klimadiagramme und klimazonale Karte Ungarns. Annales Universitatis Scientarium Budapestiensis. Sectio Biologica, 4: 21-50.

Csapó, T., Baranyai, G., Hajdú, Z., Lenner, T., ZENTAI, Z., 2012. Dunántúl: Éghajlat. In DövÉNYI, Z. (eds). A Kárpát-medence földrajza [Geography of the Carpathian-basin]. Budapest: Adadémiai Kiadó, p. 754-757.

EHRENDORFER, F. (eds), 1973. Liste der Gefässpflanzen Mitteleuropas. Stuttgart: Gustav Fischer Verlag. 318 p.

Ehrendorfer, F., HAMANN, U., 1965. Vorschläge zu einer floristischen Kartierung von Mitteleuropa. Berichte der Deutschen Botanischen Gesellschaft, 78: 35-50.

EllenberG, H., 1988. Vegetation ecology of Central Europe. $4^{\text {th }}$ edition. Cambridge: Cambridge University Press, p. 71-138.

FeKete, L., Blattny, T., 1913. Az erdészeti jelentőségü fák és cserjék elterjedése a Magyar Állam területén I.-II. [Distribution of forest tree and shrub species in the area of Hungarian State I.-II.]. Selmecbánya: Joerges Ágost özvegye és fia könyvnyomdája.

Finnie, T.J.R., Preston, C.D., Hill, M.O., Uotila, P., Crawley, M.J., 2007. Floristic elements in European vascular plants: an analysis based on Atlas florae Europaeae. Journal of Biogeography, 34: 1848-1872.

FüHrer, E., Horváth, L., Jagodics, A., Machon, A., SzABADOS, I., 2011. Application of a new aridity index in Hungarian forestry practice. Idöjárás, 115: 205-216.

Hartvig, P., VestergaArd, P. (eds), 2015. Atlas flora Danica. København: Gyldendal. 1230 p.

Haupler, H., Schonfelder, P. (eds), 1988. Atlas der Farn- und Blütenpflanzen der Bundesrepublik Deutschland. Stuttgart: Eugen Ulmer GmbH \& Co. $768 \mathrm{p}$.

Hendrych, R., Hendrychová, H., 1979. Preliminary report on the Dacian migroelement in the flora of Slovakia. Preslia, 51: 313-332. 
Jalas, J., Suominen, J. (eds), 1972-1994. Atlas florae Europaeae. Vol 1-10. Helsinki: Committee for Mapping the Flora Europe \& Societas Biologica Fennica Vanamo.

Jalas, J., Suominen, J., Lampinen, R. (eds), 1996. Atlas florae Europaeae. Vol 11. Helsinki: Committee for Mapping the Flora of Europe \& Societas Biologica Fennica Vanamo. 310 p.

Jalas, J., Suominen, J., Lampinen, R., Kurtto, A. (eds), 1999. Atlas florae Europaeae. Vol 12. Helsinki: Committe for Mapping the Flora of Europe \& Societas Biologica Fennica Vanamo. 250 p.

Jogan, N., (eds), Bačič, B., Frajman, I., Leskovar, D., Naglič, A., Podobnik, B., Rozman, S., StrgulcKRAJŠEK, B., TRČAK, B., 2001. Gradivo za atlas flore Slovenije [Materials for the atlas of flora of Slovenia]. Miklavž na Dravskem polju: Center za Kartografijo Favne in Flore. 443 p.

KaPLAN, Z., 2012. Flora and phytogeography of Czech Republic. Preslia, 84: 505-573.

KIRÁLY, G., 2003. A magyarországi flóratérképezés módszertani alapjai [The methodological foundation of Hungarian Flora Mapping]. Flora Pannonica, 1 (1): 3-20.

Kozlowski, G., Bürcher, S., Fleury, M., Huber, F., 2009. The Atlantic elements in the Swiss flora: distribution, diversity, and conservation status. Biodiversity and Conservation, 18 (3): 649-662.

KuCHARCZYK, M. (eds), 2003. Phytogeographical roles of lowland rivers on the example of the middle Vistula. Lublin: Maria-Curie-Skłodowska University Press. 127 p.

Lakatos, M., Szentimrey, T., Bihari, Z., Szalai, S., 2013. Creation of a homogenized climate database for the Carpathian region by applying the MASH procedure and the preliminary analysis of the data. Időjárás, 117 (1): 143-158.

MÁTHÉ, I., 1940. Magyarország növényzetének flóraelemei [Geoelements of the Hungarian flora]. Acta Geobotanica Hungarica, 3: 116-147.

MáTHÉ, I., 1942. Magyarország növényzetének flóraelemei II. (Geoelements of the Hungarian flora II.) Acta Geobotanica Hungarica, 4: 85-108.

Mitrakos, K., 1980. A theory for Mediterranean plant life. Oecologia Plantarum, 1: 245-252.

MolnáR, V.A. (eds), 2011. Magyarország orchideáinak atlasza [Atlas of the Hungarian orchids]. Budapest: Kossuth Kiadó. 504 p.

Niklfeld, H., 1971. Bericht über die Kartierung der Flora Mitteleuropas. Taxon, 20: 545-571.

PÉCZELY, Gy. (eds), 1981. Éghajlattan [Climatology]. Budapest: Nemzeti Tankönyvkiadó. 336 p.

RÉDEI, T., Horvát, F., 1995. A flóraelemek kategóriarendszere [Categories and system of the floristic geoelements]. In Bodrogközy, Gy., Fekete, G., Molnár, Zs., Németh, F., Priszter, SZ., Rédei, T., Simon, T. Flóra adatbázis 1.2: taxonlista és attribútum-állomány. Vácrátót: MTA Ökológiai és Botanikai Kutatóintézete. 267 p.

Pócs, T., 2000. A magyar flóra összetétele [Composition of the Hungarian flora]. In HortobáGYi, T., Simon, T. (eds). Növényföldrajz, társulástan és ökológia. Budapest: Nemzeti Tankönyvkiadó, p. 155-166.

R Development Core Team, 2008. $R$ : a language and environment for statistical computing. Vienna, Austria: R Foundation for Statistical Computing [cit. 2015-12-01]. http://www.R-project.org.

Simon, T., 1992. A magyarországi edényes flóra határozója. Harasztok-virágos növények [Identification keys of the vascular plants of Hungary.] Budapest: Nemzeti Tankönyvkiadó Rt., p. 798-874.

SLAVÍk, B., 1986. Fytokartografické syntézy ČSR [Phytocartographical syntheses of the Czech Socialistic Republic]. Vol 1. Průhonice: Botanický ústav ČSAV.

SLAvík, B., 1990. Fytokartografické syntézy ČR [Phytocartographical syntheses of the Czech Republic]. Vol. 2. Průhonice: Botanický ústav ČSAV.

SLAví, B., 1998. Phytocartographical syntheses of the Czech Republic. Vol 3. Praha: Academia. 162 p.

Soó, R., 1939. A magyar flóra arealgeographiai feldolgozása [Arealgeography of the Hungarian flora]. Acta Geobotanica Hungarica, 2: 271-273.

Soó, R., MáTHÉ, I., 1938. Magyar flóramüvek II. [Hungarian flora studies II.]. Debrecen: Debreceni Egyetem Növénytani Intézetének kiadása.

ŠİIKovÁ, I., ŠİÍK, J., HÁJeK, M., KLIMENT, J., 2010. The distribution of arctic-alpine elements within high-altitude vegetation of Western Carpathians in relation to environmental factors, life forms and phytogeography. Phytocoenologia, 40 (2-3): 189-203.

ŠTĚPÁnková, J. (eds), 2012. Phytocartographical syntheses of the Czech Republic. Vol. 4. Praha: Institute of Botany ASCR, Academia. 167 p.

Trewartha, G.T., Horn, L.H., 1980. Introduction to climate. New York: McGraw Hill. 416 p.

Welten, M., SutTer, R. (eds), 1982. Verbreitungsatlas der Farn- und Blütenpflanzen der Schweiz. Basel: Birkhäuser. $716 \mathrm{p}$.

WIL, L.M., TAMIS, V.L.M., VAN'T ZeLfDE, M., VAN DER Meijden, R., Udo de Haes, H.A., 2005. Changes in vascular plant biodiversity in the Netherlands in the 20th century explained by their climatic and other environmental characteristics. Climatic Change, 72: 37-56.

Witte, JPM., VAN Der MeiJden, R., 1995. [Distribution maps of the botanical quality in the Netherlands from Florbase]. Verspreidingskaarten van de botanische kwaliteit in Nederland uit Florbase. Groteria, 21: 3-59.

ZAJĄC, M., ZAJĄC, A. (eds), 2001a. Distribution atlas of vascular plants in Poland. Cracow, Poland: Laboratory of Computer Chorology, Institute of Botany, Jagiellonian University. 714 p.

ZAJĄC, M., ZAJĄC, A., 2001b. Zasadność wyrózniania 
“Działu Północnego” wświetle danych zasięgowych "Atlasu rozmieszczenia roślin naczyniowych w Polsce - TPOL" [The Northern Divison distinguishing in the aspect of distribution data from the "Distribution atlas of vascular plants in Poland ATPOL"]. Acta Botanica Warmiae et Masuriae, 1: $15-24$.
ZAJAC, M., ZAJAC, A., 2006. Western element in the vascular flora of Poland. Biodiversity Research and Conservation, 1-2: 57-63.

Received October 25, 2016

Accepted March 1, 2017 